http://ejtr.vumk.eu

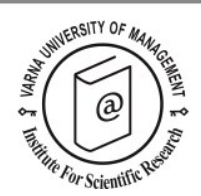

\title{
The European Journal of Tourism Research: A Personal Journey
}

\author{
Stanislav Ivanov ${ }^{1,2 *}$
}

Received: 22/01/2018 Accepted: 22/01/2018

\footnotetext{
${ }^{1}$ Editor-in-chief, European Journal of Tourism Research

2 Professor and Vice Rector (Research), Varna University of Management, 13A Oborishte str., 9000 Varna, Bulgaria; email: stanislav.ivanov@vumk.eu

* Corresponding author
}

\begin{abstract}
This paper presents an overview of the history of the European Journal of Tourism Research - the first and only English-language academic journal in the field of tourism and hospitality studies in Bulgaria. It analyses the submissions by year, type and key topics, discusses journal's policies and elaborates on the future of the journal.
\end{abstract}

(C) 2018 Varna University of Management. All rights reserved

Keywords: European Journal of Tourism Research, anniversary, editorial

Citation: Ivanov, S. (2018) The European Journal of Tourism Research: A Personal Journey. European Journal of Tourism Research 18, pp. 5-12

\section{Introduction}

In March 2018 the European Journal of Tourism Research (EJTR) celebrates 10 years of publication. As the Founding Editor and Editor-in-chief of the journal, I use this important anniversary as an opportunity to reflect on journal's history and performance during the 2007-2017 period and lay my ideas for its future development. It has been a long ride, with numerous ups and downs and a steep learning curve for me personally, which has established the EJTR as one of the leading independent journals in tourism and hospitality.

\section{Brief history of the EJTR}

The idea about the journal came to me during my visit to the College of Tourism and Hotel Management in Nicosia, Cyprus, in May-June 2006. There I worked with Dr. Craig Webster (now at Ball State University, USA) on the journal he edits: Tourism Today. His wonderful work inspired me to establish a tourism/hospitality journal in Bulgaria. Craig helped me with the concept and some initial organisational work and that is why I have always considered him as the spiritual father of the EJTR. In August 2006 I proposed the idea about the journal to Prof. Todor Radev (rector of International University College, Bulgaria, now Varna University of Management) who supported the idea and backed it financially (as he does for the last 11 years!). The initial name of the journal was going to be South-European Journal of Tourism Research (one of seven titles we discussed), but minutes before the vote of the Academic Council of my institution for the establishment of the journal I deleted the word South, which turned out to be a good decision. The Advisory and Editorial boards of the journal were formed in October-December 
2006. Here I should mention the valuable help and advice by Ercan Sirakaya-Turk, Muzzo Uysal, Craig Webster and Arie Reichel about constituting the boards. On the 31st January 2007 I sent the first call for papers for the journal. The first paper (EJTR-001) was submitted on the 6th February 2007 by Amanda K. Cecil, Yao-Yi Fu, Suosheng Wang, and Sotiris H. Avgoustis (Cecil et al., 2008). This was also the first accepted paper. In May 2007, I joined TRINet thanks to Larry Dwyer who informed me about this wonderful network and promoted the journal there.

The start of the journal was extremely difficult. I faced a lot of scepticism in my institution, in the Bulgarian and in the global tourism research communities. People just couldn't believe that someone from a country virtually unknown to the global tourism research community could lead an academic journal. My research record at that time was also very modest compared to other editors, as well as my age - I was only 28 years old when the journal was created. However, active marketing, a smooth editorial process and no compromises with quality turned out to be the winning recipe. During the first year (2007) we received 22 research papers and 6 of them were eventually accepted. The first issue of EJTR (with 3 articles and 2 book reviews) was published on 29th February 2008 and its official presentation was on the 7th March 2008 at the Salon de Wysvert conference in Stenden University, The Netherlands, thanks to the invitation I received from Dr. Sjoerd Gehrels to participate in the conference.

The visibility of any journal is of vital importance for its success (Ivanov, 2012). That is why a journal website was created (http://ejtr.vumk.eu) and contracts were signed with aggregators like ProQuest, Ebsco, CABI and DeepDyve for inclusion of the full text of the journal in their databases. The journal was also actively promoted at various tourism and hospitality conferences in order to attract the attention of the research community. Additionally, in January 2011 the Facebook page of the journal of created (https://www. facebook.com/EuroJTR/) in order to communicate with the board members, authors, readers and reviewers of the journal in social media. In 2011 this was probably one of the very first Facebook pages of a tourism/hospitality academic journal. At the time of writing of this editorial (19.01.2018), the page has been liked by 1912 Facebook users. Furthermore, in 2010 I submitted the application form for inclusion of the EJTR in Scopus. After more than a year in review, the journal was accepted for inclusion on the $2^{\text {nd }}$ June 2011 and effectively indexed in the database in November 2011. The first application for inclusion in Thomson Reuter's Web of Science (now Clarivate Analytics) was not successful, but in 2016 the journal was included in Web of Science's Emerging Sources Citation Index. At the time of writing, journal's application for inclusion in Web of Science's Social Sciences Citation Index was still under review. The inclusion of the journal in all these databases had profound positive impact on its visibility and the number of submission and citations (see further in the text). This led to an increase in the number of journal issues published per year from 2 (20082014) to 3 (from 2015 onwards).

\section{Key distinctive characteristics of the EJTR}

There are two important characteristics of the EJTR that distinguish it from the majority of other journals. First, the upper word count limit of full papers is 20000 words (excluding references). This provides much more space for authors to develop their ideas in greater depth. Second, as far as I am aware of, the EJTR was the first (and still is the only) journal in tourism and hospitality to publish structured summaries of doctoral theses in the field. When introducing this category of publications, I was led by the assumption that much of the cutting edge doctoral research does not reach the wider research community, because of various reasons - thesis language, length, online availability, etc. By publishing a 2000-word structured abstract of the thesis in English language, the global research community could get acquainted with the key content of the thesis (methodology, findings) without the need to sift through its hundreds of pages. The doctoral dissertation summaries also help young researchers with their first publication in 
Ivanov, S. (2018) / European Journal of Tourism Research 18, pp. 5-12

Table 1. Submissions to the EJTR by type, year and status

\begin{tabular}{|c|c|c|c|c|c|c|c|c|c|c|c|c|c|}
\hline Type & Status & 2007 & 2008 & 2009 & 2010 & 2011 & 2012 & 2013 & 2014 & 2015 & 2016 & 2017 & $\begin{array}{c}\text { Total } \\
2007-17\end{array}$ \\
\hline paper (full & Accepted & 6 & 7 & 9 & 13 & 7 & 15 & 21 & 26 & 29 & 37 & 17 & 187 \\
\hline research & Under review & - & - & - & - & - & - & - & - & - & - & 9 & 9 \\
\hline $\begin{array}{l}\text { note, case } \\
\text { study) }\end{array}$ & $\begin{array}{l}\text { Pending } \\
\text { revision }\end{array}$ & - & - & - & - & - & - & - & - & - & - & 14 & 14 \\
\hline \multirow[t]{2}{*}{ summary } & Rejected & - & - & - & - & - & 1 & 1 & 1 & 2 & 1 & - & 6 \\
\hline & $\begin{array}{l}\text { Pending } \\
\text { revision }\end{array}$ & - & - & - & - & - & - & - & - & - & - & 1 & 1 \\
\hline \multirow[t]{3}{*}{ Book review } & Submitted & 2 & 2 & 1 & 3 & 4 & 3 & 3 & 13 & 2 & 7 & 1 & 41 \\
\hline & Accepted & 2 & 2 & 1 & 2 & 3 & 2 & 3 & 12 & 2 & 7 & 1 & 37 \\
\hline & Rejected & - & - & - & 1 & 1 & 1 & - & 1 & - & - & - & 4 \\
\hline
\end{tabular}

Note: Submissions status as of $19^{\text {th }}$ January 2018

an academic journal. Furthermore, every year I receive 1-2 requests from readers to send them the full text of the theses whose summaries are published in the journal. How many were sent to the authors directly I do not know, but the emails from readers indicate that this type of publication stimulated some of them to look for the full text of the theses.

\section{Key statistics of submissions}

Table 1 presents the submissions to the European Journal of Tourism Research by year, type and manuscript status for the 20072017 period, while Figure 1 depicts graphically the dynamics of the total number of submissions for the same period. The start was very humble with only 24-26 submissions during the first three years of operation: 2007, 2008 and 2009. In 2010 submissions doubled and during the next three years (2010-2012) they ranged between 49 and 59. At the end of 2011 the EJTR was effectively indexed in Scopus which resulted in an increase in the number of submissions - they doubled in 2013 (88) and 2014 (105) and then doubled again: 179 submissions in 2015, 175 in 2016 and 202 in 2017. In just 10 years, the number of submissions increased 8 times! This meant that as the Editor-in-chief I was more selective,

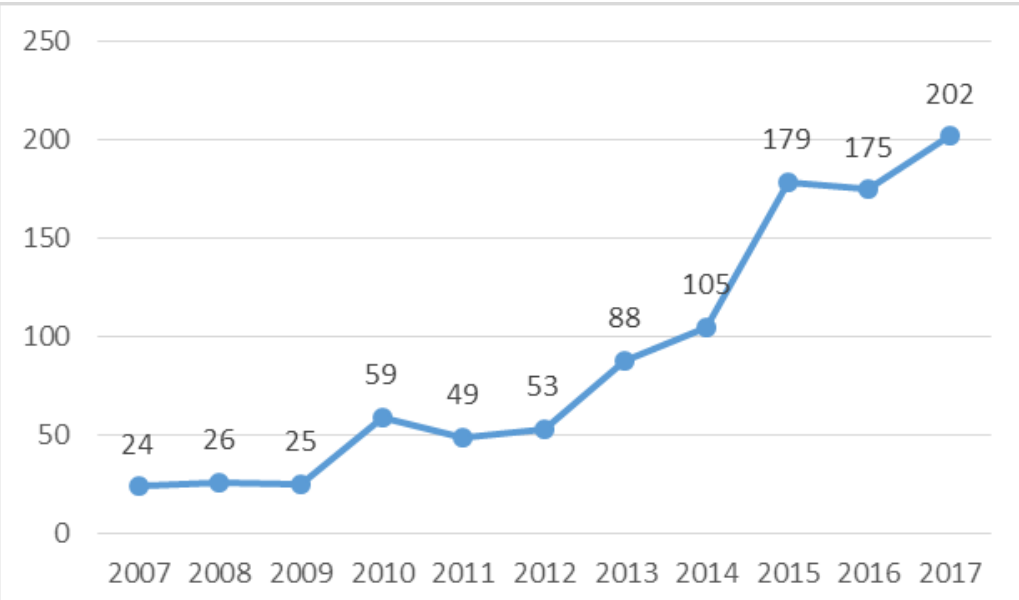

Figure 1. Total number of submissions of manuscripts to the EJTR by year 
The European Journal of Tourism Research: A Personal Journey.

leading to decrease in the acceptance rate of research papers (see Figure 2). Citations of journal's papers moved in the same direction (see Figures 3 and 4), to a great extent as a consequence of its visibility through Scopus, Web of Science, ProQuest, Ebsco, CABI and DeeepDyve, but also through promoting the journal at tourism and hospitality conferences (Ivanov, 2012).

\section{Key topics of published papers}

Research papers, published in the EJTR, cover a wide scope of topics. It is not the goal of this editorial to provide a comprehensive systematic review of all papers ever published in the EJTR. Here I summarise some of the key topic areas covered by research papers in the journal and illustrate them with a few selected references. Some of the topic areas are traditional and quite popular in tourism studies

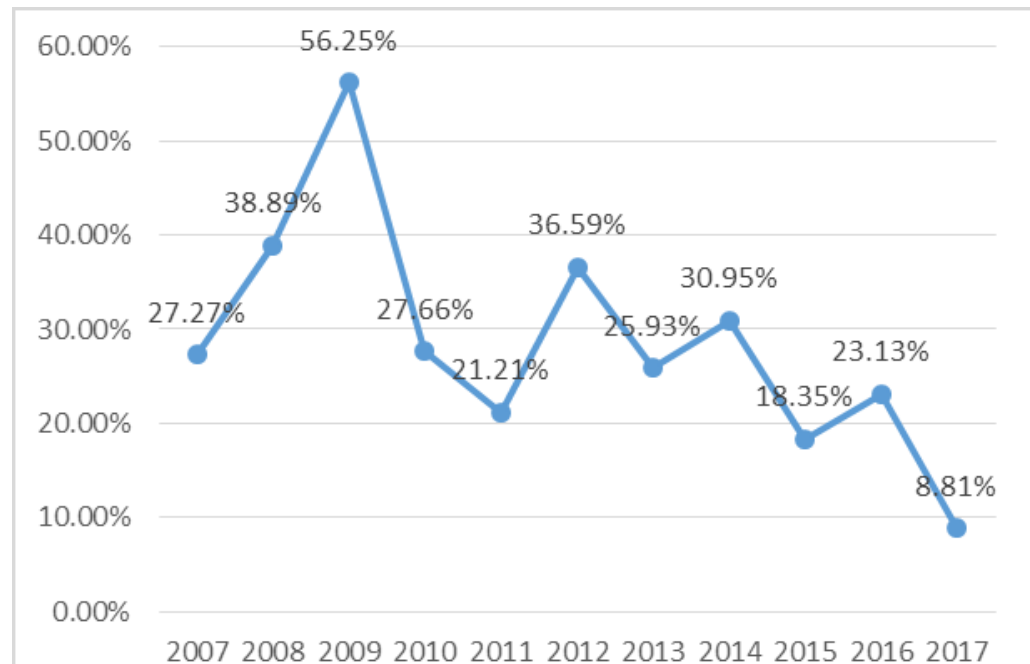

Figure 2. Acceptance rate of research papers (full papers, research notes, case studies)

Note: Data for 2017 excludes papers that were still under review or were pending revision at the time of writing the paper

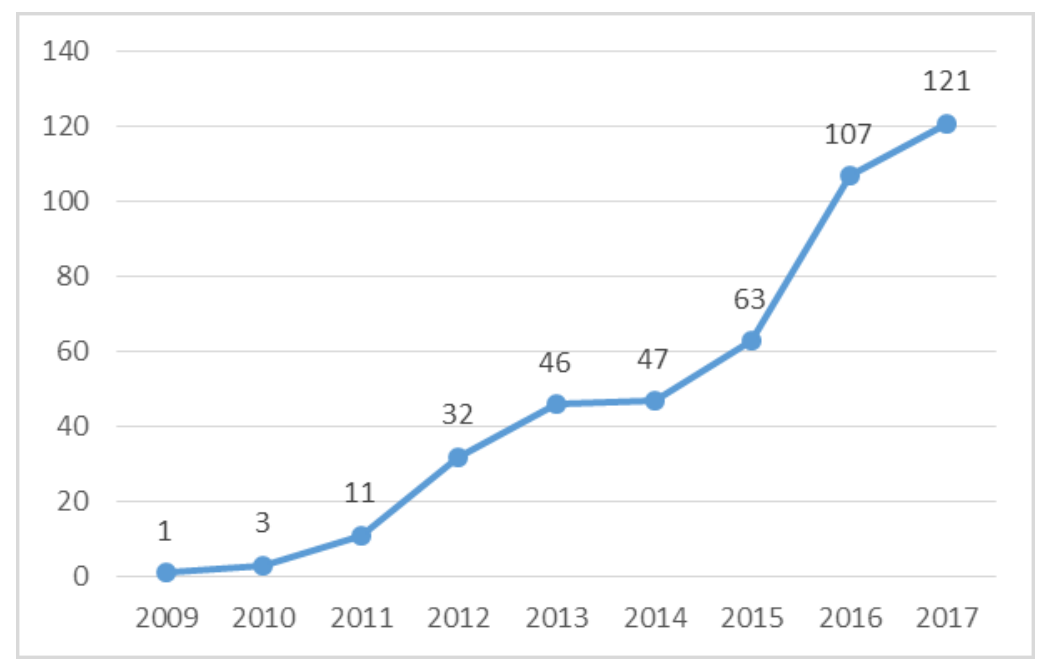

Figure 3. Number of Scopus-indexed papers, published in the respective year, that cite publications in the EJTR Note: Data of $19^{\text {th }}$ January 2018 Source: Scopus (2018) 


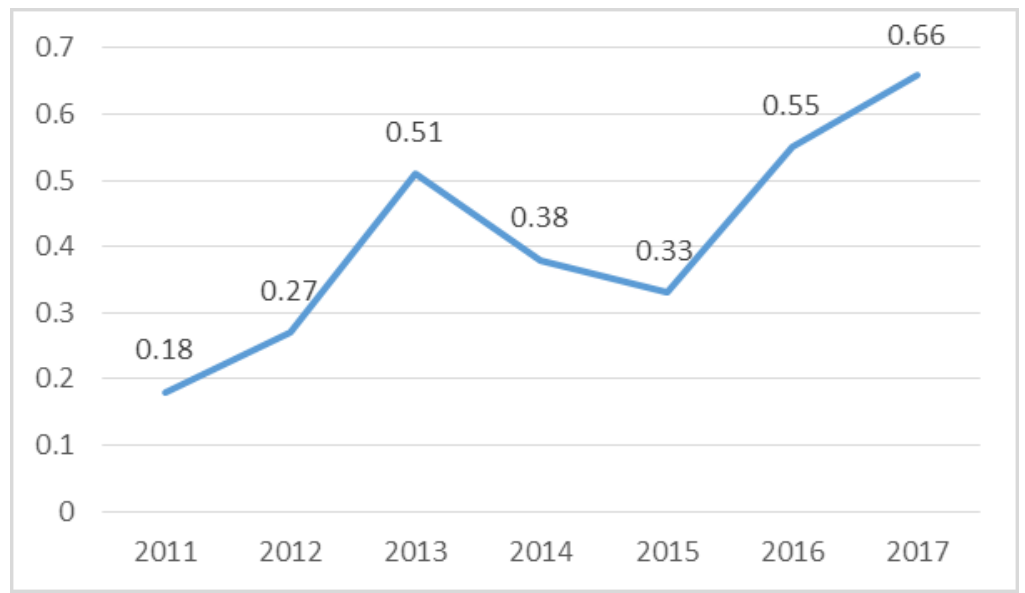

Figure 4. CiteScore of the EJTR

Note: Data for 2017 as of $11^{\text {th }}$ January 2018

Source: Scopus (2018)

(e.g. sustainability, tourism economics, destination marketing and management, types of tourism, consumer behaviour/segmentation, tourism/hospitality education, innovations in tourism, smart tourism, etc.), while other papers deal with narrower or newly emerging directions of research like robots in tourism, tourist scams, application of game theory and neural networks in tourism/hospitality, among others:

Types of tourism - rural tourism (Choo et al., 2017; Teodoro et al., 2017), social tourism (Eusébio et al., 2016), pilgrimage (Blom et al., 2016), cheese tourism (Fusté Forné, 2015), accessible tourism (Allan, 2015), residential tourism (Mantecón \& Huete, 2011), etc. Additionally, a special issue section on sport tourism, edited by Ricardo Melo and Claude Sobry, was published in Volume 16 of the journal.

$\checkmark$ Tourism economics - labour productivity (Brida et al., 2010), measuring efficiency (e.g. Andriamasy \& Rakotondramaro, 2016; Botti et al., 2009; Ratsimbanierana et al., 2013), tourism and economic growth (Brida \& Risso, 2009).

$\checkmark$ Destination marketing and management lordanova (2015), Komppula \& Laukkanen (2016), Prats et al. (2016), Pechlaner et al. (2014), among others. $\checkmark$ Sustainability - López-Sánchez \& PulidoFernández (2014), Kask et al. (2016), Ogonowska \& Torre (2013), etc.

$\checkmark$ Consumer behaviour, customer segmentation - Barić et al. (2016), Giraldi (2016), etc.

$\checkmark$ Quality of life - Cecil et al. (2008), Michalkó et al. (2013), etc.

$\checkmark$ Smart tourism - Della Corte et al. (2017), Liburd et al. (2017), etc. A special issue section devoted to smart tourism was published in Volume 17, edited by Luisa Errichiello and Roberto Micera.

$\checkmark$ Education in tourism and hospitality - e.g. Kozak \& Kozak (2014), Vodenska \& MilevaBozhanova (2017). A special issue section on tourism research and higher education in Central and Eastern Europe was edited by Jana Kucerova and Harald Pechlaner, and published in Volume 15.

$\checkmark$ Online reviews / user-generated content / social media - Pacheco (2016), Stankov et al. (2010).

$\checkmark$ Robots in tourism - Murphy et al. (2017).

$\checkmark$ Product and process innovations in tourism - Guisado-González et al. (2014).

$\checkmark$ Tourist scams - Pearce (2011).

$\checkmark$ Application of neural networks in a tourism context - Santos Silva et al. (2016).

$\checkmark$ Application of game theory in a tourism context - Jacobson et al. (2015). 
There are numerous other topic areas covered by the journal articles as well. It is evident that the readers of EJTR can find publications from a broad array of topics which they may consider suitable for their own research projects.

\section{Research ethics}

As the Editor-in-chief of the European Journal of Tourism Research I have zero tolerance towards unethical practices in any form - data fabrication, data manipulation, plagiarism, paper duplication, paper slicing, manuscript written by a paper mill, etc. Before being sent to the reviewers, every manuscript is checked for presence of unethical practices. Unfortunately, during the years I have identified 25 such submissions that had shaky research ethics. Table 2 summarises their unethical practices by type.

Plagiarism is the most common unethical practice and it is easy to prove with Turnitin, other software application or by googling some phrases from the paper. It is more difficult to identify that a manuscript was prepared by a paper mill. Usually for such manuscripts the contact email mentioned in the title page does not belong to any of the authors. A simple search in Google usually reveals that the same email address is mentioned as the contact email address for other authors of other papers. For me this is a clear signal that the email address does not belong to the authors, but to a company, specialised in fabricating manuscripts. In any case, regardless of the exact practice, manuscripts that do not adhere to the highest ethical principles in research are desk-rejected without being sent for review in line with journal's publication ethics policy.

\section{The way forward}

Much work on the journal was done since its establishment in September 2006, but much more lies ahead. Within the next 10 years the EJTR has the potential to become one of the top journals in tourism and hospitality by entering Q2 and, why not, Q1 group of journals. Of course, this probably ambitious goal would require work, unlimited devotion to quality, and active marketing, which do not frighten me. In 2015 the number of issues was increased from 2 to 3 . If the growth of submissions continues and passes the 300 submissions mark per year, the EJTR will be transformed into a quarterly publication. Inclusion of the journal in Web of Science's Social Sciences Citation Index and the calculation of an impact factor would be a key milestone to be pursued in the next couple of years.

From an operational perspective, the growth of submissions would require the reorganisation of the review process. Currently, the review process of all submissions is handled by the Editor-in-chief, which sometimes leads to inevitable delays. Delegating the review of individual submissions to handling editors is a good solution. Moving to article publication (i.e. an article is published once accepted), rather than volume publication (all articles in a volume are published simultaneously), and continuous volumes (articles are assigned page numbers in the nearest available volume once accepted) are ideas that are also considered.

A journal is as good as the articles published in it; hence, the quality of the manuscripts and the reviews will continue to be my main focus as editor. Ten years of the European Journal of Tourism Research have passed. The journal lived through its childhood period and is a teenager now. Simultaneously, I grew as a person, researcher and Editor as well and now I feel more confident in my editorial decisions than 10 years ago. I look forward to the next

Table 2. Unethical practices identified in submissions to the EJTR by type (2007-2017)

\begin{tabular}{ll}
\hline Unethical practice & Number of cases \\
\hline Plagiarism & 19 \\
Manuscript written by a paper mill & 5 \\
Paper already published in another journal & 1 \\
\hline Total & $\mathbf{2 5}$ \\
\hline
\end{tabular}


ten years when the EJTR will mature and will take its deserved place as one of the top journals in tourism and hospitality studies.

Finally, I would like to thank all the authors, reviewers, readers, guest editors, board members for their trust in the journal and for their continuous support for journal's success the Force is very strong with you and will always be! However, none of this would have been possible without the unconditional support of my family - I thank you too.

The journey goes on.

\section{References}

Allan, M. (2015) Accessible tourism in Jordan: travel constrains and motivations. European Journal of Tourism Research 10, 109-119.

Andriamasy L., H. Rakotondramaro (2016) Mean-variance-skewness in destination efficiency framework: The case of France. European Journal of Tourism Research, 14, 92-100.

Barić, D., P. Anić and M. Bedoya (2016) Segmenting protected area visitors by activities: A case study in Paklenica National Park, Croatia. European Journal of Tourism Research, 13, 103-121.

Blom, T., M. Nilsson and X. Santos (2016) The way to Santiago beyond Santiago. Fisterra and the pilgrimage's post-secular meaning. European Journal of Tourism Research 12, 133-146.

Botti, L., Peypoch, N., Robinot, E., \& Solonadrasana, B. (2009). Tourism destination competitiveness: the French regions case. European Journal of Tourism Research, 2(1), 5-24.

Brida, J. G., \& Risso, W. A. (2009). Tourism as a factor of long-run economic growth: An empirical analysis for Chile. European Journal of Tourism Research, 2(2), 178-185.

Brida, J. G., Risso, W. A., \& Carrera, E. J. S. (2010). Real wages as determinant of labour productivity in the Mexican tourism sector. European Journal of Tourism Research, 3(1), 67-76.
Cecil, A. K., Fu, Y. Y., Wang, S., \& Avgoustis, S. H. (2008). Exploring resident awareness of cultural tourism and its impact on quality of life. European Journal of Tourism Research, 1(1), 39-52.

Choo, S., K. Lee, J. Park (2017). Development of rural accommodation selection criteria: The case of South Korea. European Journal of Tourism Research, 17, pp. 246-260

Della Corte, V., C. D'Andrea, I. Savastano, and P. Zamparelli (2017). Smart Cities and Destination Management: Impacts and Opportunities for Tourism Competitiveness. European Journal of Tourism Research 17, 7-27.

Eusébio, C., M.Carneiro, E. Kastenholz and H. Alvelos (2016) The impact of social tourism for seniors on the economic development of tourism destinations. European Journal of Tourism Research 12, 5-24.

Fusté Forné F. (2015) Cheese tourism in a World Heritage site: Vall de Boí (Catalan Pyrenees). European Journal of Tourism Research 11, 87-101.

Giraldi, A. (2016) Understanding the motivation of repeat visitors to Rome. European Journal of Tourism Research 13, 43-57.

Guisado-González, M., M. Guisado-Tato, M. Rodríguez-Domínguez (2014) Testing the relationship between product innovation and process innovation. A comparative analysis of tourism and manufacturing sectors. European Journal of Tourism Research 8, 66-82

Iordanova, E. (2015) Unravelling the complexity of destination image formation: A conceptual framework. European Journal of Tourism Research 11, 35-56.

Ivanov, S. (2012). Increasing the visibility of academic journals. Strategies for Policy in Science and Education 20(1), 8-17 [in Bulgarian]. SSRN: http://ssrn.com/abstract= 1955812

Jacobson D., C. Webster, K. Shapiro, B. Musyck and S. Orphanides (2015) Cyprus settlement: a zero sum game for tourism? European Journal of Tourism Research 11, pp. 21-34 
Kask S., T. Kull and K. Orru (2016) Understanding of sustainable tourism among Russian tourism managers. European Journal of Tourism Research 14, 101-105.

Komppula, R., T. Laukkanen (2016) Comparing perceived images with projected images - A case study on Finnish ski destinations. European Journal of Tourism Research 12, 41-53.

Kozak, M., N. Kozak (2014). An analysis of postgraduate tourism education in Turkey. European Journal of Tourism Research 8, 143-147

Liburd, J., T. Nielsen, and C. Heape (2017) CoDesigning Smart Tourism. European Journal of Tourism Research, 17, 28-42.

López-Sánchez, Y., J.I. Pulido-Fernández (2014) Incorporating sustainability into tourism policy: A strategic agenda for Spain. European Journal of Tourism Research, 7, 57-78.

Mantecón, A., R. Huete (2011) Sociological insights on residential tourism: host society attitudes in a mature destination. European Journal of Tourism Research 4(2), 109-122.

Michalkó, G., M. Bakucz, T. Rátz (2013) The relationship between tourism and residents' quality of life: A case study of Harkány, Hungary. European Journal of Tourism Research 6(2), 154-169.

Murphy, J., C. Hofacker, U. Gretzel (2017) Dawning of the Age of Robots in Hospitality and Tourism: Challenges for Teaching and Research.European Journal of Tourism Research, 15, 104-111.

Ogonowska, M., D. Torre (2013) Sustainable tourism and the emergence of new environmental norms. European Journal of Tourism Research 6(2), 141-153.

Pacheco L. (2016) An analysis of online reviews by language groups: the case of hotels in Porto, Portugal. European Journal of Tourism Research, 14, 66-74.
Pearce, P.L., (2011) Tourist scams: exploring the dimensions of an international tourism phenomenon. European Journal of Tourism Research 4(2), 147-156.

Pechlaner, H., M. Bachinger, M. Volgger, E. Anzengruber-Fischer (2014). Cooperative core competencies in tourism: Combining resource-based and relational approaches in destination governance. European Journal of Tourism Research, 8, 5-19

Prats, L., R. Camprubí and L. Coromina (2016) Examining the role of familiarity, information sources, length of stay and satisfaction to the image perception model. European Journal of Tourism Research 13, 5-22.

Ratsimbanierana, H., Sbai, S., \& Stenger, A. (2013). Moroccan tourist portfolio efficiency with the mean-variance approach. European Journal of Tourism Research, 6(2), 122-131.

Santos Silva M., T. Albayrak, M. Caber and L. Moutinho (2016) Key destination attributes of behavioural intention: An application of neural networks. European Journal of Tourism Research, 14, 16-28.

Scopus (2018) European Journal of Tourism Research Journal Metrics. URL: https://www.scopus.com/sourceid/20500195 207 (accessed 19/01/2018)

Stankov, U., Lazic, L., \& Dragicevic, V. (2010) The extent of use of basic Facebook usergenerated content by the national tourism organizations in Europe. European Journal of Tourism Research, 3(2), 105-113.

Teodoro, A., I. Dinis, O. Simões, G. Gomes (2017) Success factors for small rural tourism units: an exploratory study in the Portuguese region of Serra da Estrela. European Journal of Tourism Research, 17, 136-148.

Vodenska, M., S. Mileva-Bozhanova (2017) Sixty years of tourism higher education and research in Bulgaria. European Journal of Tourism Research 15, 64-74. 